\title{
PENEGAKAN HUKUM DALAM PENANGANAN TINDAK PIDANA PENGGELAPAN
}

\author{
LAW ENFORCEMENT IN HANDLING CRIMINAL ACTIONS \\ Nurbaiti Syarif \\ Fakultas Hukum Universitas Tulang Bawang Lampung \\ nurbaity012@gmail.com
}

\begin{abstract}
Abstrak
Penggelapan dalam KUHP diklasifikasikan sebagai kejahatan. Penggelapan tersebut tertuang dalam Pasal 372 KUHP. Fokus penelitian ini pada penegakan hukum dalam menangani tindak pidana penggelapan serta faktor penghambat penegakan hukum dalam penanganan tindak pidana penggelapan. Berdasarkan hasil penelitian dan pembahasan menunjukkan penegakan hukum dalam penanganan tindak pidana penggelapan dilakukan dengan menggunakan cara non penal dan cara penal. Pendekatan non penal dilakukan dengan penyuluhan, sosialisasi dalam rangka menumbuhkan tanggung jawab sosial warga negara terhadap tindak pidana penggelapan. Penyuluhan hukum khususnya dilakukan di daerah rawan tindak pidana. Pendekatan pidana dilakukan melalui upaya hukum agar pelaku tindak pidana penggelapan diproses secara hukum guna mendapatkan sanksi pidana dan jaminan kepastian hukum. Faktor penghambat terhadap penegakan hukum dalam penanganan tindak pidana penggelapan antara lain : sanksi pidana dalam Pasal 372 KUHP belum memberikan efek jera, keterbatasan lembaga penegak hukum, terbatasnya anggaran khusus negara untuk penegakan hukum, kurangnya kesadaran masyarakat akan pentingnya memahami kejahatan, masyarakat menjadi tindak pidana.
\end{abstract}

\section{Kata Kunci: Penegakan Hukum, Kejahatan, Penggelapan.}

\begin{abstract}
Embezzlement in the Criminal Code is classified as a crime. The embezzlement is contained in Article 372 of the Criminal Code. The focus of this research is law enforcement in dealing with criminal acts of embezzlement and the inhibiting factors of law enforcement in handling embezzlement. Based on the results of research and discussion, it shows that law enforcement in handling embezzlement is carried out using non-penal and penal methods. The non-penal approach is carried out by providing counseling and socialization in the context of fostering social responsibility for citizens of the crime of embezzlement. Legal counseling is particularly carried out in areas prone to criminal acts. The criminal approach is carried out through legal measures so that the perpetrators of the criminal act of embezzlement are processed legally in order to obtain criminal sanctions and guarantee legal certainty. Inhibiting factors for law enforcement in handling criminal acts of embezzlement include: criminal sanctions in Article 372 of the Criminal Code have not provided a deterrent effect, limitations on law enforcement agencies, limited state special budget for law enforcement,
\end{abstract}


lack of public awareness of the importance of understanding crime, society becomes a criminal act.

Keywords : Law Enforcement, Crime, Embezzlement.

\section{A. Pendahuluan}

Negara Indonesia adalah negara yang berdasarkan hukum, yang mengandung makna bahwa segala tindakan serta pola tingkah laku setiap warga negaranya harus sesuai dengan norma-norma dan ketentuan-ketentuan yang diatur oleh negara. Apabila berbicara masalah hukum, maka akan dihadapkan dengan hal-hal yang berkaitan dengan kegiatan pergaulan hidup manusia di masyarakat yang diwujudkan sebagai proses interaksi dan interrelasi antara manusia yang satu dengan manusia yang lainnya didalam kehidupan bermasyarakat.

Hukum berfungsi untuk mengatur hubungan antara manusia yang satu dengan manusia lainnya dan hubungan antara manusia dan negara agar segala sesuatunya berjalan dengan tertib. Tujuan hukum untuk mencapai kedamaian dengan mewujudkan kepastian hukum dan keadilan di dalam masyarakat. Kepastian hukum menghendaki adanya perumusan kaedah-kaedah dalam peraturan perundang-undangan itu harus di laksanakan dengan tegas. Oleh sebab itu semua masyarakat Indonesia sangat mengharapkan hukum ditegakkan dan tidak boleh memihak kepada siapapun.

Negara Kesatuan Republik Indonesia merupakan negara yang berdasarkan atas hukum (rechtstaat) dan tidak berdasarkan atas kekuasaan (machtstaat). Negara hukum merupakan terjemahan dari konsep rechtstaat atau rule of law yang bersumber dari pengalaman demokrasi konstitusional di Eropa pada abad ke-19 dan abad ke-20. Oleh karena itu, ciri-ciri negara hukum antara lain : adanya supremasi hukum, jaminan hak asasi manusia, dan legalitas hukum. Di negara hukum, peraturan perundang-undangan yang berpuncak pada undang-undang dasar (konstitusi) merupakan satu kesatuan sistem hukum sebagai landasan bagi setiap penyelenggara kekuasaan.

Tindakan pidana merupakan suatu perbuatan yang melawan/melanggar hukum yang telah ditentukan. Dimana hukum yang telah ditentukan terdapat dalam Kitab Undang-Undang Hukum Pidana (KUHP). Penggelapan dalam KUHP adalah tergolong dalam kejahatan. Penggelapan terdapat dalam Pasal 372 KUHP yaitu sebagai berikut "Barangsiapa 
dengan sengaja dan dengan melawan hukum memiliki barang sesuatu yang seluruhnya atau sebagian adalah kepunyaan orang lain, tetapi berada dalam kekuasaannya bukan karena kejahatan, diancam karena penggelapan, dengan pidana penjara paling lama empat tahun atau pidana denda paling banyak sembilan ratus rupiah".

Bagi pelaku penggelapan menurut ketentuan Kitab Undang-undang Hukum Pidana Pasal 372 KUHP mengancam terdakwa dengan ancaman maksimal hukuman 4 (empat) tahun penjara. Pasal 372 ini juga menjadi dasar hukum bagi pelaku penggelapan. Jenis-jenis tindak pidana yang diatur dalam Bab XXVII dari buku II KUHP di dalam doktrin juga sering disebut tindak pidana zaakbeschadiging atau penggelapan, yang karena mendapat pengaruh dari pengaturannya di dalam Code Penal Prancis, seringkali orang menyebut tindak pidana tersebut sebagai salah satu jenis tindak pidana yang ditujukan terhadap hak milik ataupun yang oleh Simons juga disebut sebagai misdrijven tegen de eigndommen. Di dalam Undang-Undang pidana jerman, para pembentuknya hanya melarang perbuatan-perbuatan beschadigen atau merusakkan dan zestoren atau penghancuran, sedangkan di dalam KUHP yang berlaku, pembentuk Undang-
Undang ternyata telah juga melarang perbuatan-perbuatan onbruikbaar maken atau membuat hingga tidak dapat dipakai dan wegmaken atau menghilangkan disamping perbuatan-perbuatan vernielen dan beschadigen yang artinya menggelapkan. ${ }^{1}$

Pendapat bahwa melawan hukum sebagai unsur delik dalam tindak pidana di antara para pakar, tidak bulat. Sebagian pakar berpendapat bahwa jika pada rumusan suatu delik dimuat unsur melawan hukum, unsur tersebut harus dibuktikan dan sebaliknya jika tidak dirumuskan, tidak perlu dibuktikan. Hal demikian merupakan pendapat para pakar yang menganut paham formil. ${ }^{2}$

Tindak pidana kejahatan yang dilakukan perseorangan atau kelompok membuat kekhawatiran dalam masyarakat. Pemerintah bersama aparat penegak hukum sangat diharapkan perannya untuk menjaga keamanan dan ketertiban dalam kehidupan bermasyarakat. Segala tindak kejahatan perlu diproses secara hukum demi terciptanya kepastian hukum dalam masyarakat. Setiap kejahatan atau pelanggaran yang terjadi tidak hanya

\footnotetext{
${ }_{1}^{1}$ M. Yusuf, Hukim Pidana I, (Bandung : Refika Aditama, 2014), hlm. 37.

${ }^{2}$ Leden Marpaung, Asas-Teori-Praktik Hukum Pidana, (Jakarta : Sinar Grafika, 2009), hlm. 44.
} 
dilihat dari sudut orang yang melakukan kejahatan, akan tetapi dalam kasus-kasus tertentu juga dapat dilihat dari sudut korban sebagai orang yang dirugikan dalam tindak pidana tersebut.

Berdasarkan latar belakang yang telah diuraikan di atas, maka penulis hendak melakukan penelitian tentang penegakan hukum dalam penanganan tindak pidana penggelapan dan faktor penghambat terhadap penegakan hukum dalam penanganan tindak pidana penggelapan.

\section{B. Metode Penelitian}

Penelitian ini menggunakan metode penelitian yuridis normatif. Jenis bahan hukum yang digunakan meliputi bahan hukum primer dan sekunder, yang diperoleh dari bahan literatur kepustakaan dengan melakukan studi dokumen, arsip yang bersifat teoritis, konsep-konsep, doktrin dan asas-asas hukum yang berkaitan dengan pokok cara mengutip dan menelaah peraturan perundang-undangan, teori-teori dari para ahli hukum, kamus hukum, serta artikel ilmiah.

\section{Pembahasan}

\section{Penegakan Hukum dalam Penanganan Tindak Pidana Penggelapan}

Upaya penegakan hukum terhadap pelaku tindak pidana penggelapan dapat dilakukan upaya penal dengan menggunakan sarana hukum pidana (ultimum remidium). Hal ini karena mempertimbangkan frekuensi terjadinya tindak pidana penggelapan. Tindak pidana penggelapan hampir terjadi di seluruh wilayah Indonesia dan terjadi kepada seluruh masyarakat Indonesia, hanya frekuensi kejahatan ini dialami oleh masyarakat yang peluangnya lebih besar.

Penegakan hukum pidana terhadap tindak pidana penggelapan dilakukan secara tegas akan mendatangkan perasaan takut kepada para pelaku tindak pidana penggelapan yang lain untuk melaksanakan aksinya. Perasaan takut dari pelaku sehingga calon pelaku mengurungkan niatnya untuk tidak melaksanakan kejahatan tindak pidana penggelapan. Berkaitan dengan proses pembuktian oleh penegak hukum maka tindak pidana penggelapan dilakukan oleh seorang pelaku terhadap korban yang dengan maksud untuk menguasai dan menggelapkan sesuatu barang yang dimilki oleh korban. Pada tindak pidana penggelapan unsur-unsur tersebut tidak ditemukan saat mempelajari modus operandi dalam melaksanakan kejahatannya, pelaku tindak pidana penggelapan biasanya langsung 
mendatangi korban untuk suatu keperluan kejahatan, namun pembuktian mengenai tindak pidana penggelapan dilihat dari efek yang di timbulkan setelah terjadinya tindak pidana penggelapan.

Pembuktian terhadap tindak pidana penggelapan tidak difokuskan pada modusnya akan tetapi pada unsur-unsur pasalnya yang harus dibuktikan untuk menjerat pelaku tindak pidana tersebut. Proses pembuktian tersebut dimulai dengan pemeriksaan saksi-saksi, barang bukti, keterangan ahli, surat, petunjuk, sebagaimana diatur dalam pasal 184 KUHAP sebagai alat bukti yang sah. Dalam tindak pidana penggelapan, penegak hukum lebih melihat pada akibat yang ditimbulkan oleh pelaku bukan bagaimana cara pelaku melakukan tindak pidana.

Upaya penegakan hukum atau kebijakan untuk melakukan pencegahan dan penanggulangan tindak pidana penggelapan termasuk bidang kebijakan kriminal (criminal policy). Kebijakan kriminal ini pun tidak terlepas dari kebijakan yang lebih luas, yaitu kebijakan sosial (social policy) yang terdiri dari kebijakan atau upaya-upaya untuk penegakan hukum dan kebijakan atau upaya-upaya untuk perlindungan masyarakat (social defence policy). Dengan demikian, sekiranya kebijakan penanggulangan kejahatan hipnotis (politik kriminal) dilakukan dengan menggunakan sarana penal (hukum pidana), maka kebijakan hukum pidana (penal policy), khususnya pada tahap kebijakan yudikatif/aplikatif (penegakan hukum pidana in concerto) harus memperhatikan dan mengarah pada tercapainya tujuan dari kebijakan sosial itu, berupa social welfare dan social defence.

Tindak pidana penggelapan merupakan kejahatan yang belum di atur secara jelas dalam KUHP, namun telah dirasakan secara nyata oleh masyarakat efek dari tindak pidana penggelapan tersebut yakni kerugian yang ditimbulkannya. Jadi, dibutuhkan keberanian dan keyakinan hakim dalam mengambil keputusan dalam mengadilinya sesuai petunjuk-petunjuk atau alat bukti lain yang telah dihadirkan dalam pengadilan agar keadilan dapat ditegakkan.

Secara teoritis, dalam teori penegakan hukum pidana dijelaskan bahwa upaya penegakan hukum pidana dilaksanakan secara:

a) Non penal (preventif) yaitu pencegahan sebelum terjadinya kejahatan dengan lebih diarahkan kepada proses sosialisasi peraturan perundang-undangan khususnya yang mengatur mengenai kesusilaan. 
b) Penal (represif) yaitu pemberantasan setelah terjadinya kejahatan dengan dilakukannya penyidikan oleh penyidik kepolisian yang untuk selanjutnya dapat diproses melalui pengadilan dan diberikan sanksi yang sesuai dengan peraturan yang berlaku. $^{3}$

Kasus tindak pidana penggelapan, mengenai penegakan hukum pidana sebenarnya tidak hanya bagaimana cara membuat hukum itu sendiri, melainkan juga mengenai apa yang dilakukan oleh aparatur penegak hukum dalam mengantisipasi dan mengatasi masalahmasalah dalam penegakan hukum. Oleh karena itu, dalam menangani masalahmasalah dalam penegakan hukum pidana yang terjadi dalam masyarakat khususnya terhadap kasus tindak pidana penggelapan dilakukan dengan penerapan hukum pidana (criminal law application) ataupun secara preventif dan represif. Penanggulangan kejahatan merupakan suatu cara atau upaya menanggulangi adanya perbuatan yang meskipun tidak ditentukan dalam undang-undang sebagai perbuatan pidana tetapi sebagai onrecht, yaitu sebagai perbuatan yang bertentangan dengan hukum. Penegakan hukum

${ }^{3}$ Barda Nawawi Arief, Perbandingan Hukum Pidana, (Depok : Raja Grafindo Persada, 2015), hlm. 113. hendaknya dapat digunakan dalam rangka penyerasian nilai-nilai atau norma-norma yang ada pada masyarakat.

Penegakan hukum atas tindak pidana penggelapan, diterapkan dengan cara :

a) Penerapan hukum pidana (criminal law appliccdion).

b) Pencegahan tanpa pidana (prevention without punishment).

c) Mempengaruhi pandangan masyarakat mengenai kejahatan dan pendekatan melewati media massa. ${ }^{4}$

Secara teoretis bahwa penegakan hukum di atas, peneliti menganalisis bahwa dalam pengertian khusus penegakan hukum dalam penanganan tindak pidana penggelapan merupakan penerapan dengan cara penal. Pendekatan penal merupakan pendekatan dengan menggunakan sarana hukum pidana sebagaimana disebutkan dalam butir 1 penegakan hukum dan penangulangan kejahatan di atas, yakni penerapan hukum pidana (criminal law application).

Pendekatan penal merupakan pendekatan dengan menggunakan sarana hukum pidana. Upaya penal dengan menerapkan hukuman pidana formal (Ultimum Remidium) maupun hukuman pelaksanaan pidana yang dilaksanakan melalui sistem peradilan pidana. Untuk

${ }^{4}$ Ibid, hlm. 119 
mencapai tujuan yang diharapkan, tujuan dalam jangka pendek adalah resosialisasi (memasyarakatkan kembali) pelaku tindak pidana, jangka menengah adalah untuk mencegah terjadinya kejahatan dan jangka panjang merupakan tujuan akhir adalah untuk mencapai kesejahteraan sosial, sedangkan Pasal yang dikenakan adalah Pasal 372 KUHP, dimana pelaku tindak pidana penggelapan dengan modus tertentu.

Penegakan hukum dalam penanganan tindak pidana penggelapan dilaksanakan melalui pendekatan penal dilakukan dengan upaya hukum. Pelaku tindak pidana penggelapan masuk sampai ketingkat pengadilan dan mendapatkan sanksi pidana sesuai dengan ketentuan perundang-undangan yang berlaku. Upaya penal merupakan salah satu upaya yang dapat dilakukan dalam penegakan hukum pidana terhadap tindak pidana penggelapan. Upaya penal penanggulangan kejahatan dilakukan dengan hukum pidana yaitu sanksi pidana yang merupakan ancaman bagi pelakunya. Ditinjau dari KUHP maka penerapan sanksi pidana dalam KUHP tersebut merupakan bentuk upaya penal dalam menegakkan hukum tindak pidana penggelapan. Bertolak dari perkara tindak pidana penggelapan, hal ini merupakan pelaksanaan Undang-Undang melalui pendekatan penal yakni dilakukan dengan cara upaya hukum.

Peran Polri dalam penanggulangan tindak pidana penggelapan memiliki bidang yang sangat luas, tidak hanya terkait dengan tindakan pada saat sudah ada perbuatan atau ada persangkaan telah terjadi kejahatan, akan tetapi juga menjaga kemungkinan akan terjadinya kejahatan atau menanggulangi masalah kejahatan. Salah satu kebijakan dalam menanggulangi masalah kejahatan adalah kebijakan kriminal atau politik kriminal.

Secara teoritis Politik kriminal atau disebut juga dengan Criminal Policy memiliki arti sebagai berikut:

a) Dalam arti sempit adalah keseluruhan asas dan metode yang menjadi dasar dari reaksi terhadap pelanggaran hukum yang berupa pidana.

b) Dalam arti luas adalah keseluruhan fungsi dari aparatur penegak hukum, termasuk didalamnya cara kerja dari pengadilan dan polisi.

c) Dalam arti paling luas, adalah keseluruhan kebijakan, yang dilakukan melalui perundangundangan dan badan-badan resmi yang bertujuan untuk menegakkan norma-norma sentral dari masyarakat. ${ }^{5}$

${ }^{5}$ Barda Nawawi Arief, Op.Cit, hlm. 120 
Bertolak dari uraian teori di atas, peranan pengeka hukum dan pemerintah dalam melakukan penangkalan dan penanggulangan terhadap berbagai kejahatan baik yang bersifat konvensional maupun bersifat transnasional crime sangat diharapkan masyarakat. Penegakan hukum pidana khususnya pada penanggulangan tindak pidana penggelapan merupakan upaya penal dengan menggunakan sarana hukum pidana (ultimum remidium).

Upaya hukum terhadap tindak pidana penggelapan merupakan tugas dan wewenang penegak hukum. Adapun tugas dan wewenang kepolisian sesuai dengan ketentuan Undang-Undang Nomor 2 Tahun 2002 tentang Kepolisian Negara Republik Indonesia Pasal 13 sebagai berikut :

a. Memelihara keamanan dan ketertiban masyarakat.

b. Menegakkan hukum.

c. Melindungi, mengayomi, dan melayani masyarakat.

Berkaitan dengan upaya hukum terhadap tindak pidana penggelapan bahwa pada dasarnya penegakan hukum terhadap pelaku tindak pidana penggelapan berpedoman pada KUHP. Penerapan sanksi terhadap pelaku tindak pidana dilakukan secara tegas. Secara teoretis peneliti menganalisis bahwa upaya hukum terhadap tindak pidana penggelapan dilakukan oleh aparat penegak hukum termasuk bidang kebijakan kriminal (criminal policy). Kebijakan kriminal ini pun tidak terlepas dari kebijakan yang lebih luas, yaitu kebijakan sosial (social policy) yang terdiri dari kebijakan atau upaya-upaya untuk penegakan hukum dan kebijakan atau upaya-upaya untuk perlindungan masyarakat (social defence policy). Dengan demikian, sekiranya kebijakan upaya hukum terhadap tindak pidana penggelapan dilakukan dengan menggunakan sarana penal (hukum pidana) sebagai pelaksanaan dari KUHP, maka kebijakan hukum pidana (penal policy), khususnya pada tahap kebijakan yudikatif/aplikatif (penegakan hukum pidana in concerto) harus memperhatikan dan mengarah pada tercapainya tujuan dari kebijakan sosial itu, berupa social welfare dan social defence.

Penegakan hukum dalam penanganan tindak pidana penggelapan digunakan sarana penal (hukum pidana) dan sarana non penal (tanpa menggunakan hukum pidana). Adapun penjelasan penegakan hukum dalam penanganan tindak pidana penggelapan secara non penal dan secara penal sebagai berikut :

1) Upaya Penegakan Hukum Secara Non Penal (Preventif) terhadap tindak pidana penggelapan 
Usaha penanggulangan secara non penal terhadap tindak pidana penggelapan, secara tidak langsung dilakukan tanpa menggunakan sarana pidana atau hukum pidana, misalnya :

a. Penanganan objek kriminalitas di daerah dengan sarana fisik atau konkrit guna mencegah hubungan antara pelaku dengan objeknya dengan sarana pengamanan, pemberian pengawasan pada objek kriminalitas.

b. Mengurangi atau menghilangkan kesempatan berbuat kriminal dengan perbaikan lingkungan di daerah.

c. Penyuluhan kesadaran masyarakat mengenai tanggung jawab bersama dalam terjadinya kriminalitas yang akan mempunyai pengaruh baik dalam penanggulangan kejahatan.

Penegakan hukum dalam penanganan tindak pidana penggelapan bukan hanya dilakukan oleh para penegak hukum saja tetapi masyarakat juga berperan aktif membantu dan mendukung. Dengan demikian, dilihat dari politik kriminal atau kebijakan penanggulangan kejahatan secara global, maka upaya non penal merupakan upaya pencegahan sebelum terjadinya kejahatan, ini disebabkan adanya keterbatasan upaya penal, sehingga upaya non penal sangatlah penting dalam upaya penal itu sendiri.
Langkah-langkah signifikan telah diambil oleh penegak hukum untuk mengatasi tindak pidana penggelapan adalah lebih bersikap pro-aktif terhadap masyarakat dalam mencegah dan menanggulangi tindak pidana penggelapan. Adapun langkah-langkah signifikan telah diambil oleh parat penegak hukum dalam penegakan hukum dalam penanganan tindak pidana penggelapan antara lain :

a. menetapkan langkah-langkah kebijakan penegakan hukum seperti sosialisasi hukum oleh Sat Binmas dan Sat Jatanras Polres setempat terhadap tindak pidana penggelapan.

b. mengkaji dan menetapkan langkahlangkah penyelesaian dengan tugas pokok dan fungsi Polres dan Polsek dalam penegakan hukum dalam penanganan tindak pidana penggelapan.

c. melakukan koordinasi dalam sosialisasi dan pemahaman tentang penegakan hukum dalam penanganan tindak pidana penggelapan, megadakan dan meningkatkan kerjasama secara progresif dengan para Tokoh Masyarakat.

Upaya non penal yang dilakukan penegakan hukum dalam penanganan tindak pidana penggelapan adalah dengan mengadakan sosialisasi terhadap kebijakan 
penegakan hukum, koordinasi dengan sejumlah Tokoh masyarakat. Kegiatan yang dilakukan oleh Polres dan Polsek berkoordinasi dengan Tokoh masyarakat adalah bentuk upaya preventif (pencegahan/ penangkalan/ pengendalian).

Tindak pidana penggelapan tidak terlepas dari masalah pengawasan aktivitas kelompok-kelompok dalam masyarakat. Makna dari pengawasan mempunyai pengertian yang luas dan mengandung pengertian yang positif. Pengawasan berarti juga proses pengamatan seluruh kegiatan dilakukan sesuai dengan peraturan-peraturan, instruksi, dan kebijaksanaan yang berlaku. Penegakan hukum dalam penanganan tindak pidana penggelapan dalam hal ini secara preventif dilaksanakan sedini mungkin supaya tidak terjadi adanya pelanggaran-pelanggaran yang bertentangan dengan ketentuan hukum yang berlaku. Melihat fakta kasuskasus tindak pidana penggelapan, sistem pengawasan aktivitas masyarakat yang mengarah pada tindak pidana penggelapan masih kurang berjalan optimal.

Peneliti menganalisis bahwa penegakan hukum dalam penanganan tindak pidana penggelapan dengan upaya preventif dilakukan dengan pengawasan aktivitas kelompok yang mengarah pada tindak pidana namun hal ini masih kurang berjalan optimal karena berbagai faktor.
Dalam penegakan hukum pidana terhadap aktivitas masyarakat yang mengarah pada tindak pidana perusakan kendaraan secara preventif diadakan pemantapan mekanisme koordinasi dan operasi antara instansi yang terkait dalam rangka pengawasan aktivitas oknum kelompok masyarakat yang mengarah pada tindak pidana penggelapan, instansi-instansi tersebut akan melakukan tugas dan wewenangnya masing-masing sesuai dengan peraturan perundangundangan yang berlaku.

2) Upaya Penegakan Hukum Secara penal (Represif) terhadap tindak pidana penggelapan

Upaya penal merupakan salah satu upaya yang dapat dilakukan dalam tindak pidana penggelapan. Upaya penal penegakan hukum dalam penanganan tindak pidana penggelapan dilakukan dengan hukum pidana yaitu sanksi pidana yang merupakan ancaman bagi pelakunya. Upaya hukum dengan jalur penal menitikbertakan pada tindakan yang bersifat represif yaitu tindakan pemberantasan dan penumpasan untuk mengatasi masalah sosial.

Kebijakan hukum dalam upaya penanggulangan termasuk ke dalam kebijakan sosial, yaitu kebijakan atau upaya-upaya rasional dalam rangka mencapai kesejahteraan masyarakat. 
Pengenaan sanksi pidana baik berupa pidana penjara seperti tindak pidana penggelapan dilakukan melaui proses peradilan, sedangkan bagi pengenaan sanksi administrasi dapat dilakukan tanpa proses peradilan meskipun harus memperhatikan prinsip-prinsip penyelenggaraan pemerintahan yang patut.

Berdasarkan uraian tersebut dapat dianalisis bahwa kasus-kasus tindak pidana penggelapan menjadi bukti begitu pentingnya peran pemerintah dan penegak hukum, maka perlu dilakukan penegakan hukum secara komprehensif. Penegakan hukum dalam penanganan tindak pidana penggelapan secara represif dilakukan sesudah terjadinya atau adanya tindak pidana. Tindakan ini bisa bersifat yuridis dengan berdasarkan pada ketentuan dalam Pasal 372 KUHP.

Penegakan hukum kasus tindak pidana penggelapan merupakan penerapan dengan cara penal. Pendekatan penal merupakan pendekatan dengan menggunakan sarana hukum pidana sebagaimana disebutkan dalam butir 1 penegakan hukum dan penangulangan kejahatan di atas, yakni penerapan hukum pidana (criminal law application). Pendekatan penal merupakan pendekatan dengan menggunakan sarana hukum pidana. Upaya penal dengan menerapkan hukuman pidana formal (Ultimum Remidium) maupun hukuman pelaksanaan pidana yang dilaksanakan melalui sistem peradilan pidana. Untuk mencapai tujuan yang diharapkan, tujuan dalam jangka pendek adalah resosialisasi (memasyarakatkan kembali) pelaku tindak pidana, jangka menengah adalah untuk mencegah terjadinya kejahatan dan jangka panjang merupakan tujuan akhir adalah untuk mencapai kesejahteraan sosial, sedangkan Pasal yang dikenakan adalah Pasal 372 KUHP.

Penegakan hukum pidana terhadap tindak pidana penggelapan dilaksanakan melalui pendekatan penal dilakukan dengan cara upaya hukum. Pelaku tindak pidana penggelapan harus masuk sampai ketingkat pengadilan dan mendapatkan sanksi pidana sesuai dengan ketentuan perundang-undangan yang berlaku. Upaya penal merupakan salah satu upaya yang dapat dilakukan dalam penegakan hukum pidana terhadap tindak pidana penggelapan. Upaya penal penanggulangan kejahatan dilakukan dengan hukum pidana yaitu sanksi pidana yang merupakan ancaman bagi pelakunya. Ditinjau dari KUHP maka penerapan sanksi pidana dalam KUHP tersebut merupakan bentuk upaya penal dalam menegakkan hukum tindak pidana penggelapan. Hal ini merupakan pelaksanaan Undang-Undang melalui 
pendekatan penal yakni dilakukan dengan cara upaya hukum.

Penegakan hukum pidana terhadap pelaku tindak pidana penggelapan dilakukan melalui pendekatan penal yakni dengan cara upaya hukum. Upaya hukum dengan jalur penal menitikberatkan pada tindakan yang bersifat represif yaitu tindakan pemberantasan dan penumpasan untuk mengatasi masalah tindak pidana penggelapan. Kebijakan hukum dalam upaya penegakan hukum pidana terhadap tindak pidana penggelapan termasuk ke dalam kebijakan sosial, yaitu kebijakan atau upaya-upaya rasional dalam rangka mencapai kesejahteraan masyarakat. Pengenaan sanksi pidana baik berupa pidana penjara maupun pidana denda terhadap pelaku tindak pidana penggelapan harus dilakukan melaui proses persidangan peradilan, sedangkan bagi pengenaan sanksi administrasi dapat dilakukan tanpa proses persidangan peradilan meskipun harus memperhatikan prinsip-prinsip penyelenggaraan pemerintahan yang patut.

Penegakan hukum terhadap tindak pidana penggelapan perlu menjadi objek kajian bagi aparat penegak hukum dalam rangka mencegah dan menanggulangi tindak pidana tersebut. Sebagai bentuk penegakan hukum tindak pidana penggelapan maka diperlukan koordinasi dari masyarakat dengan aparat penegak hukum, karena konsep dari perwujudan penegakan hukum yang terpadu pada hakekatnya merupakan penyerasian nilainilai dan norma-norma dalam masyarakat.

\section{Faktor Penghambat Terhadap Penegakan Hukum dalam Penanganan Tindak Pidana Penggelapan}

Problematika terhadap penegakan hukum dapat terjadi apabila terdapat ketidakserasian antara nilai, kaidah, dan pola perilaku. Teori yang dipergunakan dalam menjawab permasalahan dalam penelitian yakni teori penegakan hukum pidana yang mengemukakan bahwa dalam penegakan hukum dipengaruhi oleh beberapa faktor. Berdasarkan penelitian yang telah dilakukan, diperoleh data atas permasalahan mengenai faktor penghambat terhadap penegakan hukum dalam penanganan tindak pidana penggelapan sebagai berikut :

a. Faktor perundang-undangan (substansi hukum)

Secara konseptual maka penegakan hukum dalam penanganan tindak pidana penggelapan berlandaskan pada dasar yurudis Pasal 372 KUHP. Sanksi pidana tersebut bertujuan guna menjamin kepastian hukum, ketertiban dan perlindungan hukum pada modernisasi dan 
globalisasi saat ini dapat terlaksana, namun sanksi pidana tersebut dinilai masih sangat rendah. Sanksi pidana yang sangat rendah tersebut belum memberikan efek jera kepada para pelaku tindak pidana penggelapan.

Salah satu faktor penghambat penegakan hukum dalam penanganan tindak pidana penggelapan dapat dilihat dari undang-undang yang mengatur tindak pidana penggelapan sanksinya belum cukup untuk memberikan efek jera yakni dengan ancaman pidana penjara paling lama empat tahun atau pidana denda paling banyak sembilan ratus rupiah.

Negara memberikan dasar yuridis Pasal 372 KUHP terhadap tindak pidana penggelapan namun, fakta yang terjadi di lapangan menunjukkan bahwa sanksi pidana dalam KUHP tersebut belum cukup untuk memberikan efek jera terhadap pelaku penegakan hukum dalam penanganan tindak pidana penggelapan, hal tersebut dapat dilihat dari masih terjadinya hambatan penegakan hukum dalam penanganan tindak pidana penggelapan. Hambatan dalam penegakan hukum dalam penanganan tindak pidana penggelapan dapat ditekan apabila sanksi yang diberikan kepada pelaku memberikan efek jera baik terhadap pelaku maupun terhadap masyarakat luas secara tidak langsung. Jika undang-undang yang mengatur tentang tindak pidana penggelapan itu sendiri sanksinya belum cukup untuk memberikan efek jera dan juga belum adanya peraturan pelaksanaan yang sangat dibutuhkan untuk menerapkan Undang-undang, hal ini tentunya akan memperngaruhi pelaku terus-menerus melakukan tindak pidana penggelapan.

b. Faktor Penegak Hukum

Penegak hukum yang diharapkan masyarakat adalah penegak hukum yang mempunyai kualitas dalam menyelesaikan suatu perkara sesuai dengan kejahatan yang dilakukan oleh para pelaku kejahatan. Penegak hukum yang berkualitas artinya mampu menerapkan dan menegakkan hukum yang ada di dalam KUHP serta peraturan perundangundangan untuk menjerat para pelaku kejahatan sesuai dengan proses pembuktian yang telah dilakukan para penegak hukum.

Penegak hukum harus memiliki sikap yang tanggap dan cepat dalam menangani pengaduan maupun laporan dari masyarakat atas terjadinya tindak pidana, tentu saja akan menegakkan hukum dengan baik dan sempurna. Begitu juga sebaliknya, apabila penegak hukum tidak memiliki sikap yang professional dalam hal sikap yang tanggap dan cepat, tentu saja kaidah hukum tersebut tidak dapat ditegakkan sebagaimana mestinya. 
Penegak hukum yang tidak professional khususnya dalam hal sikap yang kurang tanggap dan cepat merupakan salah satu faktor penghambat penegakan hukum dalam penanganan tindak pidana penggelapan sehingga masih terjadi tindak pidana penggelapan dan belum dapat ditangani degan maksimal.

Peneliti menganalisis bahwa faktor penegak hukum yang kurang profesional dapat mengakibatkan terhambatnya penegakan hukum dalam penanganan tindak pidana penggelapan. Penegak hukum yang kurang profesional sudah pasti tidak mampu melakukan investigasi secara benar sesuai dengan perundangundangan yang berlaku, sehingga penegak hukum tersebut justru menerapkan Pasal yang tidak sesuai dengan kaidah hukum yang berlaku. Penegak hukum yang professional selalu diharapkan masyarakat sehingga bisa menjamin kepastian hukum dan memberikan rasa nyaman kepada masyarakat dengan cara menerapkan hukum yang sesuai dengan tindak pidananya.

Secara teoritis fungsi khusus hukum pidana dalam rangka memberikan jaminan kepastian dan perlindungan hukum hal ini merupakan fungsi sekunder hukum pidana yaitu untuk menjaga agar penguasa dalam menanggulangi kejahatan itu melaksanakan tugasnya sesuai dengan aturan yang digariskan dalam hukum pidana.

Peneliti menganalisis bahwa kurang berjalannya pelaksanaan penegakan hukum dalam penanganan tindak pidana penggelapan disebabkan oleh terbatasnya personil penyidik dalam lingkup tugas yang menangani bidang kejahatan dan kekerasan (Jatanras) dalam hal melakukan penegakan hukum, penyelidikan, penyidikan dan upaya paksa selain itu aparat penegak hukum masih terbatas dalam menangani berbagai kasus tindak pidana penggelapan.

Selanjutnya dari hasil penelitian dianalisis bahwa terhambatnya penegakan hukum dalam penanganan tindak pidana penggelapan karena memang terbatasanya personil aparat penegak hukum yang sungguh-sungguh dalam penegakan hukum penanganan tindak pidana penggelapan.

c. Faktor Sarana atau Fasilitas yang Mendukung

Penegakan hukum akan berlangsung dengan baik apabila didukung dengan sarana dan fasilitas yang cukup yang digunakan untuk mencapai tujuan. Sarana dan fasilitas tersebut mencakup tenaga manusia yang berpendidikan dan terampil, peralatan yang memadai, dana yang cukup dan sebagainya. Jika hal-hal tersebut tidak 
terpenuhi, maka penegakan hukum akan sulit tercapai tujuannya dengan sempurna.

Beberapa hambatan yang mempengaruhi kinerja para penegak hukum dalam melaksanakan tugasnya dalam menangani kasus tindak pidana penggelapan antara lain:

1) Terbatasnya jumlah aparat penegak hukum yang ada di lapangan untuk mengawasi dan mengantisipasi adanya tindak pidana penggelapan.

2) Terbatasnya biaya operasional yang terkadang harus menggunakan biaya operasional pribadi.

3) Kurangnya sarana yang mengakibatkan penegakan hukum dalam penanganan tindak pidana penggelapan dilakukan tidak secara penuh dan total.

Penegakan hukum dalam penanganan tindak pidana penggelapan kurang maksimal atau dapat dikatakan kurang dapat berjalan disebabkan karena tidak adanya sarana atau prasarana yang memadai kemudian terbatasnya anggaran operasional khusus dari negara untuk penegakan hukum dalam penanganan tindak pidana penggelapan dan belum dibentuknya Tim Khusus Pengawas dan Pemantauan penegakan hukum dalam penanganan tindak pidana yang berkoordinasi dengan pihak terkait yang khusus mengawasi kegiatan para pelaku tindak pidana penggelapan.

Secara teoritis pelaksanaan fungsi hukum pidana dalam rangka penegakan hukum dalam penanganan tindak pidana penggelapan dapat diartikan sebagai sarana penanggulangan kejahatan, namun fakta di lapangan dalam upaya mewujudkan penegakan hukum dalam penanganan tindak pidana penggelapan mengalami berbagai hambatan khususnya terkait faktor fasilitas atau sarana dan prasarana dari pemerintah yang kurang begitu memperhatikan betapa pentingnya akibat tindak pidana penggelapan.

Penegakan hukum dalam penanganan tindak pidana penggelapan masih menuai hambatan disebabkan karena terbatasanya personil aparat penegak hukum khusus bidang Jatanras, terbatasanya sarana atau prasarana yang kurang memadai kemudian tidak adanya anggaran khusus dari negara untuk penegakan hukum dalam penanganan tindak pidana penggelapan. Selain itu, perlengkapan yang dibutuhkan yang belum lengkap dapat mengakibatkan kinerja Aparat penegak hukum belum maksimal.

\section{d. Faktor Masyarakat}

Persoalan penegakan hukum dalam penanganan tindak pidana penggelapan merupakan suatu persoalan yang terkadang diabaikan. Masyarakat pada umumnya 
kurang mengetahui arti pentingnya penegakan hukum dalam penanganan tindak pidana penggelapan bisa dilihat masih banyaknya oknum masyarakat menjadi pelaku tindak pidana penggelapan tersebut. Masyarakat lainnya yang segan untuk melapor kepada pihak yang berwajib membuat penegak hukum sulit memberantas para pelaku tindak pidana tersebut. Kesadaran hukum masyarakat yang masih rendah membuat penegakan hukum dalam penanganan tindak pidana penggelapan.

Penegakan hukum dalam penanganan tindak pidana penggelapan masih kurang optimal salah satu faktor penghambatnya yakni masyarakat kurang memahami dan tidak mengerti betapa pentingnya masalah tindak pidana, masih banyak masyarakat pada khususnya tidak sadar akan hukum yang berlaku sehingga hal tersebut dapat memicu terhambatnya penegakan hukum dalam penanganan tindak pidana penggelapan.

\section{e. Faktor budaya}

Budaya oknum masyarakat yang melakukan tindak pidana perusakan kendaraan juga merupakan penghambat dalam penegakan hukum dalam penanganan tindak pidana penggelapan. Sulit untuk mengubah budaya lama karena memang sudah sejak lama budayanya seperti itu.
Berdasarkan uraian di atas, dapat dianalisis bahwa lemahnya penegakan hukum sebenarnya tidak selalu dari struktur kelembagaan yang tidak independen dan lemahnya aturan perundang-undangan. Namun juga berbagai faktor yang mempengaruhinya. Pangkal tolak dari kesemua itu adalah profesionalitas aparat penegak hukum. Penegak hukum pada hakikatnya komitmen dalam penegakan hukum dalam penanganan tindak pidana penggelapan. Selain kualitas para penegak hukum, substansi hukum tidak luput dari perbaikan. Substansi hukum merupakan peraturan yang dipakai oleh para pelaku hukum pada waktu melakukan perbuatanperbuatan serta hubungan hukum atau dengan kata lain mencakup segala apa yang merupakan keluaran dari suatu sistem hukum, termasuk dalam hal ini norma hukum baik yang berupa peraturan, keputusan, doktrin sejauh semuanya itu digunakan dalam proses yang bersangkutan.

Hambatan dalam penegakan hukum dalam penanganan tindak pidana penggelapan seyogianya dapat diminimalisir. Tentunya disini dibutuhkan adanya peran aktif, kejujuran, dan ketelitian dari aparat penegak hukum. Bila tidak maka hanya akan menimbulkan permainan hukum atau pun koruptifitas 
saja. Keberhasilan dalam penegakan hukum dalam penanganan tindak pidana penggelapan ini tentunya akan membawa kemajuan besar bagi masyarakat. Berdasarkan kelemahan-kelemahan dan permasalahan yang ada, pada prinsipnya aspek yang penting untuk ditempuh adalah mencoba mewujudkan penegakan hukum secara terpadu mulai dari unsur Pemerintah dan Penegak hukum serta melibatkan pula beberapa instansi terkait, dalam penegakan hukum dalam penanganan tindak pidana penggelapan.

\section{Kesimpulan}

Berdasarkan analisis hasil penelitian dan pembahasan, dapat disimpulkan sebagai berikut bahwa penegakan hukum dalam penanganan tindak pidana penggelapan dilaksanakan dengan menggunakan sarana non penal dan sarana penal.

Pendekatan non-penal dilakukan dengan penyuluhan, sosialisasi dalam rangka mengembangkan tanggung jawab sosial warga masyarakat sadar akan tindak pidana penggelapan, penyuluhan hukum khususnya dilakukan dilingkunganlingkungan yang rawan dengan kejahatan, penanganan objek kriminalitas. Pendekatan penal dilakukan dengan cara upaya hukum yakni pelaku tindak pidana penggelapan diproses hukum berdasarkan ketentuan peraturan perundang-undangan sampai ketingkat pengadilan dan eksekusi guna mendapatkan sanksi pidana dan menjamin kepastian hukum.

Faktor penghambat terhadap penegakan hukum dalam penanganan tindak pidana penggelapan sebagai berikut:

a. Faktor hukum, sanksi pidana dalam Pasal 372 KUHP belum memberikan efek jera kepada para pelaku tindak pidana penggelapan.

b. Faktor penegak hukum, keterbatasan aparat penegak hukum dalam penegakan hukum dalam penanganan tindak pidana penggelapan. Selain itu, tindakan dan sikap aparatur penegak hukum yang masih koruptif dalam menegakkan hukum. Sehingga membuat pelaksanaan fungsi hukum juga kurang efisien.

c. Faktor fasilitas, keterbatasan anggaran khusus dari negara penegakan hukum dalam penanganan tindak pidana penggelapan seperti belum dibentuknya Tim Khusus Pengawas dan Pemantauan tindak pidana penggelapan yang berkoordinasi dengan pihak terkait yang khusus mengawasi tindak pidana penggelapan.

d. Faktor masyarakat, kurangnya kesadaran masyarakat akan pentingnya pemahaman tindak pidana penggelapan. Selain itu masyarakat bersikap acuh tak acuh, tidak ada kepedulian karena perbuatan tersebut oleh masyarakat dianggap suatu hal yang biasa. 
e. Faktor budaya, budaya masyarakat yang sebagian masyarakatnya menjadi oknum tindak pidana. Sulit untuk mengubah budaya lama karena memang sudah terbentuk sejak lama.

\section{Daftar Pustaka}

\section{Buku}

Barda Nawawi Arief, Bunga Rampai Kebijakan Hukum Pidana, Bandung : Citra Aditya Bakti, 2002.

, Masalah Penegakan Hukum dan Kebijakan Penanggulangan Kejahatan. Bandung : Citra Aditya Bakti, 2001.

\section{Perbandingan Hukum}

Pidana, Depok : Raja Grafindo Persada, 2015.

Romli Atmasasmita, Sistem Peradilan Pidana Kontemporer, Jakarta : Kencana, 2010.

Erna Dewi, Hukum Penitensier Dalam Perspektif, Bandar Lampung : Lembaga Penelitian Universitas Lampung, 2013.

Maidin Gultom, Penegakan Hukum Pidana, Bandung : Refika Aditama, 2014.

Leden Marpaung, Asas-Teori-Praktik Hukum Pidana, Jakarta : Sinar Grafika, 2009.

Poernomo, Asas-Asas Hukum Pidana, Ghalia Indonesia, Bandung, 2013.

Wirjono Prodjodikoro, Hukum Pidana, Bandung : Refika Aditama, 2009.
Suroso, Imam, Hukum Acara Pidana, Karakteristik Penghentian Penyidikan dan Implikasi Hukumnya, LaksBang Pressindo, Yogyakarta, 2016.

Sudarto, R., Hukum Pidana, Yayasan Sudarto, Fakultas Hukum UNDIP. Semarang, 1997.

Soerjono Soekanto, Pengantar Penelitian Hukum, Jakarta : UI Press, 1986. , Terminologi Penegakan

Hukum, Jakarta : UI Press, 1986.

Suharto dan Jonaedi Efendi, Panduan Praktis Bila Anda Menghadapi Perkara Pidana Mulai Proses Penyelidikan Hingga Persidangan, Prenada Media Group, Jakarta, 2014.

Yusuf, M., Hukim Pidana I, Refika Aditama, Bandung, 2014.

\section{Peraturan Perundang-Undangan}

Undang-Undang Nomor 1 Tahun 1946 jo Undang-Undang Nomor 73 Tahun 1958 tentang Pemberlakuan Kitab Undang-Undang Hukum Pidana (KUHP).

Undang-Undang Nomor 8 Tahun 1981 tentang Hukum Acara Pidana (KUHAP).

Undang-Undang Nomor 2 Tahun 2002 tentang Kepolisian Negara RI. 